\title{
Improving written communication among English language learners
}

\author{
MJ Outcault Hill, MA \\ faith.orillaza@westcliff.edu
}

Robert M. Caldwell, PhD

cbls@aol.com

\begin{abstract}
Teachers of English language learners (ELL) face two important tasks. First, they must help students master the content of a specific subject matter and compile evidence that students can demonstrate mastery. Second, they must help students achieve proficiency in academic English, both orally and in writing. In this short article, the authors would like to share some of the practical techniques researchers have found for helping students master the content of a specific subject matter and offer suggestions to help ELL students begin mastering the difficult task of communicating in writing.
\end{abstract}




\section{Introduction}

To begin, the challenge of teaching subject matter content is addressed well in an article by Karen Carrier (2006) entitled, "Improving Comprehension and Assessment of English Language Learners Using MMIO." Carrier (2006) offers effective techniques for addressing the problem of helping ELL students master school content. Her suggestions and practical ideas warrant review by any teacher searching for ways to improve the teaching of subject matter content to ELL's. Many of Carrier's (2006) techniques, however, are less reliant on developing written English and "...are more dependent on using multiple modes of input and output" (p. 1). While using Carrier's (2006) multiple modes may well promote the learning of content, they only partially address the development of written language; and at some point, learners must develop proficiency in both oral and written communication.

\section{Discussion}

Carrier (2006) proposes using what she terms Multiple Modes of Input and Output (MMIO), a method which provides many opportunities for developing procedural knowledge and critical thinking. For example, some of what she proposes is as follows:

1) Emphasis on specialized vocabulary for a specific subject matter.

2) Using graphic organizers.

3) Use of computer-based word processing technology to produce comprehensible output in short bulleted points of key information, which reduces the language load for ELL's.

That being said, teachers of English language learners continue to search for effective, empirically-based methods of helping individuals acquire and use the English language for oral and written communication. In a 2014 review of literature by Caldwell and Outcault entitled "Identifying and Implementing Specific Cognitive Processes that Affect Composition Skills Used in Selected Writing Genres," the authors conclude that little research has been done on the cognitive aspects of writing and that a great deal more research is needed on how ELL writers go about intellectualizing their thoughts and constructing ideas in written language.

Surprisingly, little research has been done on the exact cognitive processes writers use to transform their own experiences onto the written page. Caldwell and Outcault (2014) cite 
the work of Lola et al. (2011) and Bereiter and Scardamalia (1993) on the differences between beginning writers' (knowing little of the English language) and expert writer's (more proficient in the knowledge of English) characteristics and how cognitive functions are used in the process of writing. The research of Bereiter and Scardamalia (1993) stands out as an example of researchers who have advanced the development of research frameworks for linking cognitive processes with the development of written language.

Further research exploring the function of the cognitive aspects of writing in terms of language learners, has been advanced by Flower and Hayes (1981), Cumming (1989), and Sasaki (2000). Sasaki's (2000) study of first and second language writers constructing language revealed distinct differences in their cognitive planning of verbal practice and written words on paper. Sasaki (2000) found that second language learners "self-regulate" through a verbal-towritten process more frequently than first language writers (p. 258).

What does research suggest as good practice in helping English language learners with written language? Scardamalia's (1981) research is founded on a Constructivist notion that students use language to construct knowledge. Therefore, one effective technique used in her research for helping students develop language skills is termed "knowledge telling," a process in which students tell what they know. This strategy consists of telling what one knows in more or less the order it comes to mind with genre constraints and preceding text as the principal retrieval clues.

Scardamalia (1981) believes this to be a highly efficient strategy that enables young writers, and writers with limited skill in the English language, to quickly and easily complete writing assignments that more mature writers labor over. Her research shows that the more mature writers, or those more proficient in the English language, employ a more complex strategy of knowledge transformation which involves a cycling between writing concerns and concerns about knowledge. Although less efficient in getting the job done, the more mature writer's strategy has the important benefit that the writer's knowledge of language undergoes development through the composing process, whereas knowledge telling has little or no effect on the writer's actual knowledge. 
The distinction between these ways of producing knowledge has become increasingly relevant with the advent of computer technologies. Studies conducted by Corbeil (1989) found that the use of word processing technologies helped learners easily create language, and therefore knowledge, and offered unique advantages to helping second language learners develop improved learning skills.

For example, the application of word processing in a network environment allowed students to create documents and then share them with other students in a student-to-student interaction that benefited students in improving their vocabulary, comprehension, and interpretation.

Other studies by Kobayashi \& Rinnert (1992) also offer some useful effects of first language on second language writing through translation versus direct composition. These studies of various English compositions written by 48 Japanese university students examined differences between writing resulting from two writing processes: one group of learners writing first in Japanese and then translating into English and the other group composing directly in English. What the studies found was the relationship between these two writing processes and students' language proficiency. In terms of quality of content, organization, and style, lowerlevel writers (writers with low proficiency in English) tended to benefit from translation, whereas higher-level writers (greater proficiency in English) did not benefit much. Overall, syntactic complexity was greater in translations than in direct writings. In terms of error frequency, higher-level students tended to make more errors that interfered with intended meaning in translation than in direct writing, but lower-level students did not show any difference.

Regarding the correlation between language proficiency and the quality of the writing resulting from the two composing processes, oral skills related more closely to writing quality than did grammar knowledge, particularly for direct writing.

As teachers of learners who struggle to comprehend and communicate in the English language, we continue to search for ways to improve that complex learning process. In this short article, we have tried to summarize what some researchers have found to be effective in improving both the learning of subject matter content and the improvement of written 
language. As a final note, we would add that one factor that seems to contribute significantly to helping learners gain knowledge and improve the quality of their writing is their response to teacher feedback.

Caldwell and Outcault Hill (2017) suggest that meaningful instructor feedback must do more than simply focus on the correction of punctuation, grammar, spelling, and vocabulary. Feedback must be provided in a way that facilitates an evolution in academic writing and English acquisition. It must help the learner extend intellectual thought and exercise cognitive process beyond knowledge and comprehension levels. In order to compile evidence that students can demonstrate subject matter mastery, research on the effectiveness of currently accepted corrective practice, utilized by educators, warrants further investigation. There is currently little satisfactory research evidence to support the practice that error correction methods are helping learners improve written expression significantly (Truscott, 1996). In addition, there is much evidence to support the idea that many students fail to take advantage of instructor feedback and use it to improve their written communication (Bitchener_\& Knoch, 2008).

\section{Conclusion}

It is the hope of the authors that the suggestions detailed above might have some practical applications in actual classrooms and that the thoughts expressed here might provide some directions for further research with validation. In addition, it is our hope that educators will extend current research and contribute to the base of empirical research contributing to better helping learners master English. 


\section{REFERENCES}

Bitchener, J., \& Knoch, U. (2008). The value of written corrective feedback for migrant and international students. Language Teaching Research, 12(3), 408-431.

Caldwell, R. M., \& Outcault, M. J. (2014). Identifying and Implementing Specific Cognitive Processes that Affect Composition Skills Used in Selected Writing Genres. Second Annual Research Symposium at the University of Phoenix Southern California Campus.

Caldwell, R., \& Hill, M. J. (2017). Research in writing instruction: Current and needed research to improve student writing. Westcliff International Journal of Applied Research, 1 (1).

Capps, R., Fix, J., Murray, J., Ost, J., Passel, J., \& Herwantoro, S. (2005). The new demography of America's schools: Immigration and the no child left behind act. Washington, D.C.: The Urban Institute.

Carrier, K. A. (2006) Improving comprehension and assessment of English language learners using MMIO. The Clearing House, 79(3), 131-136.

Corbeil, G. (1989). Adult second language learners: Fostering higher levels of constructive processes in response to corrective feedback. (Unpublished doctoral thesis). University of Toronto, Toronto.

Kobayashi, H., \& Rinnert, C. (1992). Effects of first language on second language writing: Translation versus direct composition. John Wiley \& Sons. DOI: 10.1111/j.1467-1770. 1992.tb00707.x

Scardamalia, M. (1981). How children cope with the cognitive demands of writing. In C. H. Frederiksen \& J. F. Dominic (Eds.), Writing: The nature, development and teaching of written communication (81-103). Hillsdale, NJ: Lawrence Erlbaum Associates.

Scardamalia, M., \& Bereiter, C. (1983). The development of evaluative, diagnostic, and remedial capabilities in children's composing. In M. Martlew (Ed.), The psychology of written language: Developmental and educational perspectives (67-95). London: John Wiley and Sons.

Scardamalia, M., Bereiter, C., McLean, R.S., Swallow, J., \&Woodruff, E. (1989). Computersupported intentional learning environments. Journal of Educational Computing Research, 5, 51-68.

The national clearinghouse for English language acquisition and language instruction educational programs. (2007). Retrieved from ww.ncela.gwu.edu/expert/fastfaq/4.html

Truscott, J. (1996). The case against grammar correction in L2 writing classes. Language Learning, 46, 327-369. 